\title{
Pengaruh Penggunaan Berbagai Bahan Sumber Karbohidrat terhadap Kualitas Silase Pucuk Tebu
}

\author{
Effect Of The Use Various Materials Carbohydrate Sources On The Quality \\ Sugarcane Top Silage
}

\author{
N. Jamarun, I. Ryanto dan L. Sanda \\ Bagian Nutrisi dan Teknologi Pakan, Fakultas Peternakan \\ Universitas Andalas, Padang \\ E-Mail: novirman@yahoo.com \\ (Diterima: 05 Januari 2014; Disetujui: 14 Maret 2014)
}

\begin{abstract}
ABSTRAK
Penelitian ini bertujuan untuk menentukan kualitas silase pucuk tebu yang terbaik, berdasarkan parameter warna, bau, $\mathrm{pH}$, tekstur dan total jamur dengan suplementasi berbagai sumber karbohidrat sebagai bahan additif. Penelitian dilaksanakan di Laboratorium Nutrisi Ruminansia, Fakultas Peternakan, Universitas Andalas dengan menggunakan Rancangan Acak Lengkap (RAL). Perlakuan adalah 4 macam sumber karbohidratyang digunakan sebagai bahan additif yaitu : (A)dedak, (B) tepung jagung, (C) tepung sagu dan (D) tepung tapioka dengan 5 ulangan setiap perlakuan. Supplementasi bahan-bahan tersebut adalah $10 \%$ dari bahan kering pucuk tebu. Hasil penelitian menunjukkan bahwa pemakaian berbagai bahan sumber karbohidrat (dedak, jagung, sagu, dan tapioka) tersebut dengan penambahan $10 \%$ dari bahan kering pucuk tebu, memberikan pengaruh yang berbeda nyata $(\mathrm{P}<0.05)$ terhadap warna, bau dan $\mathrm{pH}$ silase pucuk tebu, sedangkan parameter tekstur dan total jamur dari silase yang dihasilkan ternyata berpengaruh tidak nyata $(\mathrm{P}>0.05)$.Dari hasil penelitian dapat disimpulkan bahwa perlakuan B (penggunaan additif tepung jagung) memberikan hasil silase yang terbaik dibandingkan dengan sumber karbohidrat lainnya.
\end{abstract}

Kata kunci : sumber karbohidrat, silase pucuk tebu, tepung jagung, dedak dan tepung sagu

\section{ABSTRACT}

This experiment aim to determine the effect of supplementation of several carbohydrates sources on the quality of sugarcane top silage. There were 4 sources of carbohydrates used as treatments were : Rice brand (A), Corn meal (B), Sago meal (C) and Cassava meal (D). Supplementation of carbohydrates sources were $10 \%$ of dry matter basis of sugarcane top. The parameter measure were : colour, smell, texstur, $\mathrm{pH}$ and mold percentages. This experiment was conducted at Ruminant Nutrition laboratory, Faculty of Animal Science, Andalas University. The experiment using completely randomized design with 4 treatments and 5 replications for each treatment. The results of the experiment indicated that supplementation of rice brand (A), corn meal $(B)$, sago meal $(C)$ and cassava meal $(D) 10 \%$ of dry matter basis had significant effect $(P<0.05)$ on colour, smell, and $p H$ but no significant effect $(P>0.05)$ on texstur and total mold of sugarcane top silage. The best silage treatment in this experiment was addition of corn meal as additive to sugarcane top silage compared to the other souces of carbohydrates.

Keywords : carbohydrate sources, sugarcane top silage, corn meal, rice brand, sago meal 


\section{PENDAHULUAN}

Limbah perkebunan pada saat ini mempunyai peluang yang besar untuk dimanfaatkan sebagai pakan ternak dan tentu saja pengelolaannya perlu dilakukan secara tepat, sehingga ketersediaannya berkesinambungan. Limbah (by product) yang mempunyai potensi untuk digunakan sebagai pakan ternak adalah pucuk tebu. Pembuatan silase pucuk tebu merupakan salah satu cara yang harus dilakukan agar bahan pakan ini dapat tersedia sepanjang tahun, disamping juga untuk menekan biaya dan memperpanjang masa simpan.

Proses pembuatan silase (ensilase) adalah melalui pengawetan bahan pakan yang umumnya terdiri dari hijauan (limbah hijauan) melalui proses fermentasi dalam suatu tempat (silo) dalam kondisi kedap udara atau anaerob (Lubis, 1963). Pada kondisi tersebut bakteri an-aerob akan berkembang dengan cepat, terutama bakteri pembentuk asam laktat sehingga akan menghasilkan silase yang baik dan mengurangi/menghambat pertumbuhan jamur pembusuk dan ragi (Ensminger,1971).

Menurut Pangestu (2003), beberapa keuntungan limbah pucuk tebu jika dijadikan sumber pakan bagi ternak ruminansia adalah karena tanaman ini lebih toleran terhadap musim panas, tahan terhadap hama dan penyakit serta dapat tumbuh pada musim kemarau. Pemanenan tebu dilakukan terutama untuk memenuhi kebutuhan pabrik gula, agar dapat selalu berproduksi secara optimal, sehingga limbah yang diperoleh cukup banyak sepanjang tahun sedangkan penggunaannya oleh peternak belum terlalu banyak (Hernaman et al., 2005).

Melimpahnya produksi pucuk tebu, tentu memerlukan pengawetan agar tahan lama dan salah satu cara untuk itu adalah membuat silase pucuk tebu. Lubis (1963), menyatakan bahwa pembuatan silase tidak tergantung kepada cuaca, sehingga merupakan cara pengawetan paling baik di daerah tropis.

Mc Ilroy (1997) menyatakan bahwa jika cara pembuatan silase baik, maka nilai gizinya hampir sama dengan nilai gizi segarnya. Cullison (1982) mengemukakan bahwa setiap tanaman sebenarnya dapat dijadikan silase, dengan syarat tanaman tersebut mengandung air yang cukup, mengandung sejumlah karbohidrat dan zat-zat makanan lainnya serta mudah memperolehnya. Sumber karbohidrat sebagai additif yang biasa dipakai untuk pembuatan silase yaitu tepung sagu, dedak, tepung jagung dan tepung tapioka.

Kualitas silase tidak hanya diukur dari segi kecernaan ataupun kandungan gizi saja tetapi juga diukur berdasarkan warna, bau, tekstur, $\mathrm{pH}$ dan jumlah jamur.

\section{METODE}

Penelitian ini dilakukan secara eksperimen dengan menggunakan rancangan acak lengkap (RAL). Sebagai perlakuan adalah beberapa jenis sumber karbohidrat yang mudah larut (water soluble carbohydrate) yaitu (A: dedak $10 \%$, B: tepung jagung $10 \%$, C: tepung sagu $10 \%$ dan D: tepung tapioka $10 \%)$ dengan 5 ulangan. Bila didapatkan hasil yang berbeda nyata antar perlakuan maka dilanjutkan dengan uji Duncan Multiple Range Test (DMRT) untuk melihat perbedaan antar perlakuan (Steel and Torrie, 1995). Peubah yang diamati dalam penelitian ini adalah warna, bau, tekstur, $\mathrm{pH}$ dan total jamur dari silase pucuk tebu.

\section{HASIL DAN PEMBAHASAN}

Pengamatan kualitas Silase Pucuk Tebu secara Organoleptik (Warna dan bau), tekstur, $\mathrm{pH}$ dan total jamur dapat dilihat pada Tabel 1.

Dari penilaian warna silase pucuk tebu (Tabel1) diperoleh nilai yang tertinggi adalah 33,40 pada perlakuan B (tepung jagung), sedangkan nilai terendah adalah 29,00 pada perlakuan C (tepung sagu). Hasil uji statistik menunjukkan bahwa pemberian berbagai sumber karbohidrat pada pucuk tebu memberikan hasil yang berbeda nyata $(\mathrm{P}<0,05)$ terhadap warna silase dan setelah dilakukan uji DMRT ternyata perlakuan A (dedak) memberikan hasil yang berbeda nyata $(\mathrm{P}<0,05)$ terhadap perlakuan $\mathrm{C}$ dan $\mathrm{D}$ tapi berbeda tidak nyata $(\mathrm{P}>0,05)$ dengan perlakuan $\mathrm{B}$. Reksohadiprodjo et al., (1985), menyatakan bahwa perubahan warna yang terjadi pada 
Tabel 1. Rataan nilai organoleptik (warna dan bau), tekstur, $\mathrm{pH}$ dan total jamur silase pucuk ebu

\begin{tabular}{lccccc}
\hline \multicolumn{1}{c}{ Perlakuan } & Warna & Bau & Tekstur & pH & Jamur \\
\hline A. Dedak & $31,00^{\mathrm{a}}$ & $40,40^{\mathrm{a}}$ & 30,20 & $4,38^{\mathrm{b}}$ & 63,46 \\
B. Tepung Jagung & $33,40^{\mathrm{a}}$ & $41,60^{\mathrm{a}}$ & 28,80 & $4,68^{\mathrm{a}}$ & 49,16 \\
C. Tepung sagu & $29,00^{\mathrm{b}}$ & $38,60^{\mathrm{ab}}$ & 31,60 & $4,30^{\mathrm{bc}}$ & 53,73 \\
D. Tepung Tapioka & $29,20^{\mathrm{b}}$ & $35,20^{\mathrm{b}}$ & 29,40 & $4,20^{\mathrm{c}}$ & 39,14 \\
\hline
\end{tabular}

Keterangan : superskrip yang berbeda menunjukkan pengaruh berbeda nyata $(\mathrm{P}<0,05)$ antar perlakuan.

tanaman dalam proses ensilase disebabkan oleh proses respirasi aerob yang berlangsung selama persediaan oksigen masih ada sampai gula tanaman habis. Gula akan teroksidasi menjadi $\mathrm{CO} 2$ dan air, panas juga dihasilkan pada proses ini, sehingga temperatur naik. Temperatur yang tidak terkendali menyebabkan silase berwarna coklat tua sampai hitam. Hal ini menyebabkan turunnya kandungan nutrisi pakan, karena banyaknya sumber karbohidrat yang hilang dan kecernaaan protein akan turun. Keadaan ini terjadi pada tempreratur $55^{\circ} \mathrm{C}$. Menurut Ensminger (1971), warna coklat tembakau, coklat kehitaman, warna caramel (gula bakar) atau gosong menunjukkan warna silase yang erat hubungannya dengan tingkat kebusukan.

Ditinjau dari bau silase pucuk tebu (Tabel 1) ternyata perlakuan B (tepung jagung) memiliki nilai tertinggi yaitu 41,60 dibandingkan dengan perlakuan A (dedak): 40,40, C (tepung sagu): 38,60 dan D (tepung tapioka): 35,20 . Hasil uji statistik menunjukkan bahwa pemberian berbagai sumber karbohidrat pada pucuk tebu memberikan hasil yang berbeda tidak nyata $(\mathrm{P}<0,01)$. Setelah dilakukan uji DMRT perlakuan B (jagung) merupakan perlakuan tertinggi dengan nilai rataan 41,60 berbeda tidak nyata $(\mathrm{P}<0,05)$ dengan perlakuan A (dedak) dan berbeda tidak nyata ( $\mathrm{P}>0,05)$ dengan perlakuan $\mathrm{C}$ (tepung sagu) dan perlakuan D (tepung tapioka). Perlakuan dedak (A) berbeda tidak nyata $(\mathrm{P}>0,05)$ dengan perlakuan $\mathrm{C}$ (tepung sagu), tetapi berbeda nyata $(\mathrm{P}<0,05)$ dengan perlakuan $\mathrm{A}$ (tepung jagung) dan $\mathrm{C}$ (tepung tapioka). Dalam penelitian ini perlakuan D mempunyai bau asam dan busuk. Silase yang berbau busuk terdapat pada silase dengan penambahan tepung tapioka, dimana hal ini disebabkan karena aktivitas bakteri sakarolitik terhadap gula atau asam laktat menghasilkan asam butirat (Mc. Cullough, 1978). Bila udara masuk ke dalam silo akan menyebabkan pertumbuhan mikroorganisme aerobik, aktivitas pernapasan akan menghasilkan panas dan meningkatkan temperatur yang menyebabkan terjadi pembusukan. Kebusukan yang terjadi apabila pemadatan dalam silo juga kurang baik (Susetyo, 1980). Siregar (1996) menyatakan bahwa, secara umum silase yang baik mempunyai ciri-ciri rasa dan bau asam, tetapi segar dan enak.

Dilihat dari tekstur silase pucuk tebu (Tabel 1) ternyata perlakuan yang menggunakan tepung sagu memiliki nilai tertinggi yaitu 31,60 dibandingkan dengan dedak $(30,20)$, tepung jagung $(28,80)$ dan tepung tapioka $(29,40)$. Hasil uji statistik menunjukan bahwa pemberian berbagai sumber karbohidrat pada silase pucuk tebu memperlihatkan tekstur yang berbeda tidak nyata $(\mathrm{P}>0,05)$. Dari uji statistic terlihat bahwa perlakuan yang menggunakan tepung jagung merupakan perlakuan terbaik dengan nilai 31,60, namun berbeda tidak nyata $(P>0,05)$ antar semua perlakuan. Semua silase bertekstur lembut, tidak rusak dengan skor 3. Silase yang teksturnya agak rusak diberi skor 2 dan yang teksturnya kasar atau rusak diberi skor 1 . Hal ini menunjukkan bahwa pembuatan silase dengan pemberian berbagai sumber karbohidrat memberikan hasil silase yang baik dari segi tekstur. Menurut Siregar (1996), secara umum silase yang baik mempunyai ciri-ciri tekstur lembut masih jelas seperti alamiah.

Dilihat dari pH Silase pucuk tebu (Tabel 1) ternyata perlakuan B (tepung jagung) 
memiliki nilai tertinggi yaitu 4,68 dibandingkan dengan perlakuan A $(4,38), \mathrm{C}(4,30)$ dan D $(4,20)$.Rataan Nilai pH Silase Pucuk Tebu Setelah dilakukan uji DMRT ternyata perlakuan B (jagung) merupakan perlakuan terbaik dengan nilai 4,68 dan berbeda nyata $(\mathrm{P}<0,05)$ dengan semua perlakuan lainnya. Perlakuan A (dedak) berbeda tidak nyata $(\mathrm{P}>0,05)$ dengan perlakuan D (tapioka) tetapi berbeda nyata $(\mathrm{P}<0,05)$ dengan perlakuan $\mathrm{B}$ dan $\mathrm{C}$. Berdasarkan hasil penelitian, pucuk tebu yang diberi berbagai sumber karbohidrat dalam jangka waktu 30 hari dan dianalisis dengan Analisis of Varian (ANOVA), menunjukan bahwa pemberian berbagai sumber karbohidrat menghasilkan perbedaan yang sangat nyata $(\mathrm{P}<0,01)$ terhadap parameter $\mathrm{pH}$. Penurunan $\mathrm{pH}$ silase pada penelitian ini disebabkan oleh asam yang dihasilkan bakteri Asam Laktat (BAL) selama ensilase. Wallace dan Chesson (1995), menyatakan bahwa asam yang dihasilkan selama ensilase adalah asam laktat, propionate, formiat, suksinat dan butirat. Siregar (1996), mengkategorikan kualitas silase berdasarkan pH-nya yaitu : 3,5-4,2 baik sekali, 4,2-4,5 baik, 4,5-4,8 sedang dan lebih dari 4,8 adalah silase yang jelek. Kategori tersebut didasarkan pada silase yang dibuat menggunakan bahan pengawet. Bahan pengawet yang biasa ditambahkan untuk memenuhi kecukupan karbohidrat yang mudah larut yang berguna untuk fermentasi, terutama untuk mempercepat penurunan $\mathrm{pH}$ (Matsuhima, 1979). Secara keseluruhan penambahan BAL akan memberikan silase yang baik dengan $\mathrm{pH}$ antara 4,0-4,5. Menurut McDonald et al., (1991), dengan menjaga kondisi lingkungan tetap anaerob dan asam ( $\mathrm{pH}$ sekitar 4), silase akan dapat disimpan dalam jangka waktu yang lama tanpa kerusakan. Johnson et al.,(2005), melaporkan penggunaan vakum pada silo plastik skala laboratorium dengan penggunaan inokulum akan menghasilkan pH 3,94 sedangkan jika tanpa inokulum pH akan 4,21. Hal ini menunjukkan bahwa inokulum sangat berperan dalam proses fermentasi silase.

Parameter total jamur pada silase pucuk tebu dapat dilihat pada Tabel 1. Perlakuan C (sagu) memiliki nilai tertinggi dari total jamur silase yaitu 31,60 dibandingkan dengan (A) dedak $(30,20)$, (B) jagung $(28,80)$ dan (D) tapioka $(29,40)$. Hasil uji statistik menunjukkan bahwa pemberian berbagai sumber karbohidrat pada silase pucuk tebu memberikan hasil berbeda tidak nyata $(\mathrm{P}>0,05)$ terhadap total jamur. Hasil penelitian menunjukan bahwa pemberian berbagai sumber karbohidrat tidak berpengaruh nyata terhadap total jamur silase pucuk tebu. Hal ini disebabkan karena dalam proses ensilase, bakteri asam laktat dapat berkembang dengan baik karena pemberian dedak, jagung, sagu dan tapioka sebagai sumber karbohidrat yang menstimulir perkembangbiakan bakteri pembentuk asam laktat. Stoskops (1981) menyatakan bahwa jamur akan tumbuh pada keadaan aerob yang menyebabkan silase menjadi apek dan berjamur. Selanjutnya Woolford (1984), menyatakan bahwa Filamentous fungi tidak banyak mempengaruhi proses ensilase tetapi dapat menyebabkan banyaknya silase yang terbuang terutama pada permukaan akibat adanya kemasukan udara. Jamur biasanya tumbuh pada bagian atas atau bagian sisi dari silo dan jumlahnya sangat tergantung pada padat atau tidaknya bahan di dalam silo (Mc. Collough, 1978).

\section{KESIMPULAN}

Berdasarkan hasil penelitian dapat disimpulkan bahwa suplementasi berbagai sumber karbohidrat pada ensilase pucuk tebu memberikan pengaruh yang nyata terhadap warna, bau, dan $\mathrm{pH}$ namun berpengaruh tidak nyata terhadap tekstur dan total jamur silase pucuk tebu. Silase pucuk tebu yang terbaik diperoleh pada suplementasi dengan tepung jagung.

\section{DAFTAR PUSTAKA}

Cullison, A. E. 1982. Feeds and Feeding. Reston Pub. Inc, Virginia.

Ensminger, M. E. J. E. Oldfield. 1971. Feeds and Nutrition. The Ensminger Publishing Company, California.

Hernaman, I. 2005. Pengaruh penggunaan molases dalam pembuatan silase 
campuran ampas tahu dan pucuk tebu kering terhadap nilai $\mathrm{pH}$ dan komposisi zat-zat makanannya. Jurnal Ilmu Ternak.

Johnson, H. E., R. J. Merry, D. R. Davies, D. B Kell, M. K. Theodorou, and G. W. Griffith. 2005. Vacuum packing : A model system for laboratory scale silage fermentation. Journal Of Applied Microbiology 98: 106-113.

Lubis, D. A. 1963. Ilmu Makanan Ternak. PT Pembangunan. Jakarta.

Matsuhima, J.K. 1979. Feeding Beef Cattle. Sprenger Verlag, Berlin Heidelberg, New York.

McDonald, P., A.R. Henderson and S.J.E. Heron. 1991. The Biochemistry of Silage. Britain : Chalcombe Publication.

Mc. Collough, M. E. 1978. Silage Some General Consediration Fermentation Silage A Review. Ed. By Mc Collough National Feed Ingredients Association. Iowa.

Mc. Donald, P. 1981. The Biochemistry of Silage. John Wiley and Sons. New York.

Mc. Ilroy, R. J. 1997. Pengantar Budidaya Padang Rumput Tropika. Pradnya Paramita. Jakarta.
Pangestu, E. 2003. Evaluasi potensi nutrisi fraksi pucuk tebu pada ternak ruminansia. Med. Pet. 5: 65-70.

Reksohadiprodjo, S., B. Suhartanto, S.P. Sasmitobudhi, dan M. Soeyono. 1985. Konsumsi bahan kering, energi dan protein tercerna pucuk tebu dan limbah pertanian lain pada kmbing dan domba. Proceedings Seminar Pemanfaatan Limbah Tebu untuk pakan ternak. Pusat Pengembangan Peternakan Departemen Pertanian. Bogor. 1(12): 66-73.

Siregar, M.E. 1996. Pengawetan Pakan Ternak. Penebar Swadaya. Jakarta.

Steel, R. G. D. dan J. H. Torrie. 1995. Prinsip dan Prosedur Statistik. Penerjemah : Sumantri, B. Jakarta: PT. Gramedia Pustaka Utama.

Stoskops, N. C. 1981. Understanding Crop Production. Reston Publishing Company, Inc. Reston. Virginia.

Susetyo, S. 1980. Padang pengembalaan. Fakultas Peternakan Institut Pertanian Bogor. Bogor.

Wallace, R.J. and C. Chesson. 1995. Biotechnology in Animal Feeds and Animal Feeding. Winheim. Ithaca and London.

Woolfrod, M. K. 1984. The Silage Fermentation. Marcel Dekker, Inc. New York 